\title{
ISOLATION AND PHYTOCHEMICAL TEST OF ANTICANCER ISOLATE OF SPONGE Hyrtios erecta
}

\author{
I Made Dira Swantara ${ }^{1}$, Wiwik Susanah Rita ${ }^{1}$, Rr. Anisa Hernindy ${ }^{1}$ \\ ${ }^{1}$ Applied Chemistry, Graduate School, University of Udayana \\ Jalan Sudirman, Denpasar \\ m_dira_swantara@yahoo.co.id
}

\begin{abstract}
AbstractThis research aims to isolate and phytochemically test of the toxic isolate from ethanol extract of the sponge Hyrtios erecta taken from the waters of Pari Island beach. Thousand Islands (Jakarta). Extraction of the sponges was carried out by $70 \%$ ethanol at room temperature. Partition and purification of the compounds were done by column chromatography with the stationary phase of silica gel and the mobile phase of n-hexane-chloroform (2:8). Toxicity screening test was done based on Bhrine Shrimp Lethality Test (BSLT). The compounds of the active isolate were performed by phytochemical test. Based on the results, it was found that the toxic isolate of Hyrtios erecta sponges has anticancer activity with IC50 of 30,497 ppm. The anticancer isolate contained alkaloid, steroid, and polyphenol compounds
\end{abstract}

Keywords: phytochemical test, anticancer, Hyrtios erecta

\section{INTRODUCTION}

Recently, cancer is one of the leading causes of death in developing countries. In the United States and some other developed countries, cancer is currently responsible for around $25 \%$ of all deaths. Within a year, about $0.5 \%$ of the death population was diagnosed cancer [10]. WHO also stated that a third to half of cancers can be prevented. Another third can be cured if found and treated at an early stage / early stage, but the rest can only be alleviated his suffering.

Despite intensive efforts cancer treatment has been carried out, but no one has found a drug that can overcome the disease satisfactorily. This is due to the low selectivity of drugs used [22]. A wide variety of compounds have been developed against cancer which includes compounds alkylating, antimetabolite, radiomimetik drugs, hormones, and antagonist compounds [4], [2], [9], [12], but none of these types of compounds produce a satisfactory effect and no adverse side effects [7], [8]. Chemotherapy is one of the main treatment of cancer, but the toxicity and side effects are very large. Therefore we need an alternative traditional medicine using local materials cheaper, easily available, and also without leaving any side effects for patients. That is what led to the current began much research on the anticancer drug ingredients derived from nature. Search anticancer active ingredients from nature is not only derived from terrestrial organisms but has expanded to marine organisms.
Indonesian marine biodiversity provide opportunities to explore marine life to the search of new bioactive compounds, one of which is a sponge. The sponge is one of the organisms of coral reef that have the potential bioactivity. Bioactive compounds produced by sponges are a source of new compounds that have pharmacological activity that can be used as a drug because it has toxic properties to kill cancer cells [1]. Various studies have been conducted to identify the biological activity possessed by the sponge of the type Hyrtios erecta $(H$. erecta). Pettit mentioned that $H$. erecta contained some active compounds, such as spongistatin which are anticancer compounds, 15-oxopupeheonol as inhibiting cancerous cells and malaria, sesterpen 1that inhibit cell leukemia, and dipupehedion as an inhibitor of cancer cells [16].

One method used to conduct pre screening of the active anticancer compound is a cytotoxicity assay against the larvae of Artemia salina Leach or Brine Shrimp Lethality Test (BSLT) [19], [20]. The high toxicity of the test compound is highly correlated with the activity of anticancer compounds [14], [15]. A material that has a lethal concentration of $50 \%\left(\mathrm{LC}_{50}\right)$ is lower than $1000 \mathrm{ppm}$, the material has potential as an anticancer agent [18], [21].

\section{METHODS AND PROCEDURE}

\section{E. Materials}

Sponges $H$. erecta was taken from the waters of Pari Island, Thousand Islands, Jakarta, on August 1, 2016 
(reproduced the sample). The sample was cleaned of impurities with tap water until clean, then it dried at room temperature for several days. After drying, subsequently it ground to the degree of fineness of 100 mesh.

\section{F. Extraction of Metabolites}

A total of 500 grams of powder samples was extracted with $70 \%$ ethanol until submerged and left to stand for 24 hours, then filtered. The filtrate was collected and the waste was added again the same solvent until submerged. This work was repeated 3-4 times until all the estimated extractable compounds. The filtrate collected was evaporated with a rotary vacuum evaporator until all the solvent evaporates, thus obtained crude extract.

\section{G. Separation and Purification of Metabolites}

The crude extract was dissolved in $250 \mathrm{~mL}$ of ethanol-water (3:7) until all dissolved, then ethanol was evaporated. Water extract was then partitioned with nhexane $(3 \times 100 \mathrm{~mL})$. $\mathrm{n}$-hexane layers were separated and the water layer was re partitioned with chloroform $(3 \times 100$ $\mathrm{mL}$ ) and then separated in order to obtain n-hexane extract $(\mathrm{EH})$, chloroform extract (EK) and extract water (EW). The third extract was evaporated until solvent runs out. The toxicity test of the three extracts was conducted. The most toxic extracts are then separated. As much as 2 grams of the most toxic extract was separated using silica gel column chromatography (100 grams) with the best eluent from separation by thin layer chromatography (TLC). The eluate was accommodated each $5 \mathrm{~mL}$ in particular bottle to approximately all components out of the column. The stain patterns of all eluates were evaluated on TLC. The eluates with the same stain patterns were combined in order to obtain several fractions. All fractions obtained were tested the toxicity against the larvae of A. salina. The most toxic fraction was subsequently tested anticancer activity against $\mathrm{HeLa}$ cells and the compounds in the active isolate were identified.

\section{H. Toxicity Test}

Toxicity test using bio-indicator of A.salina larvae followed the method of Meyer [14]. Media for A. salina larvae hatch was made by filtering sea water. The sea water was put into the aquarium divided into two parts, one part was made of dark covered with black paper and the other part was left open. A. salina eggs laid moderation on the part of dark and left to stand for $2 \times 24$ hours so that the eggs hatch into larvae that was ready for testing.

Weighing $20 \mathrm{mg}$ of substance to be tested was dissolved in $2 \mathrm{~mL}$ of $\mathrm{n}$-hexane. From this solution was taken 500; 50; and $5 \mu \mathrm{L}$, then each inserted into a test tube and the solvent evaporated. Into each test tube added $1 \mathrm{~mL}$ of seawater, $50 \mu \mathrm{L}$ of dimethylsulfoxide, 10 larvae. Then the sea water was add to get volume of $5 \mathrm{~mL}$, in order to obtain the concentration of the extract on each tube: 1000 ; 100; and $10 \mathrm{ppm}$. Extract with concentration of $0 \mathrm{ppm}$ (without the addition of extract)was made as a control. Each test tube was covered with aluminum foil and hollowed out a bit and then left at room temperature. After 24 hours, the observation on larval mortality was carried out. The number of dead larvae were recorded, then count of $\mathrm{LC}_{50}$.

\section{Anticancer Test}

Anticancer test using HeLa cells. Cervical cancer cells (HeLa) were cultured in RPMI 1640 medium, calculated the initial number of cells under a microscope. Then the cells were harvested by adding trypsin. Furthermore, the cells were centrifuged to form two layers (sediment and supernatant). The supernatant was discarded and the sediment was formed pellets and added $1 \mathrm{~mL}$ complete media, then counted the number of cells using a hemocytometer. Once sufficient cells, the cells were grown in 96 wells of microwell plate. Each of the wells contained $2 \times 10^{4}$ cells in $100 \mu \mathrm{L}$. Cells were incubated for $1-2$ hours so that the cells attached. After that, the extracts were added of various concentrations $(1000 ; 500 ; 250 ; 125 ; 62.5 ; 31.25$; $15.62 ; 7.81 ; 3.91 ; 1.95 ; 0.97 ; 0.48 ; 0.24 ; 0.12$; and 0.06 $\mu \mathrm{g} / \mathrm{mL}$ ) in each well of $100 \mu \mathrm{L}$. So the total of each well contained $200 \mu \mathrm{L}$. The cells were incubated in the incubator for 24 hours at $37^{\circ} \mathrm{C}$. After 24 hours, they were seen under a microscope, added MTT (3- (4,5-dimetiltiazol-2-yl) -2,5difeniltetrazolium bromide) $(5 \mu \mathrm{g} / 1 \mathrm{~mL})$ at each well, then incubated for 4 hours. The next stop solution of SDS (sodium dodecyl sulphate) $10 \%$ in $0.01 \mathrm{~N} \mathrm{HCl}$ was added to each well and incubated again one night. The absorbance was read using an ELISA reader at a wavelength of $550 \mathrm{~nm}$.

\section{J. Phytochemicals Test}

The active anticancer Isolates were analyzed the group chemical compounds including: testing of alkaloid,; flavonoids, triterpenoids/steroids, polyphenols, and saponins.

\section{RESULTS AND DISCUSSION}

\section{A. Extraction of Metabolites}

Extraction of 500 grams of sponge Hyrtios erecta powder using $70 \%$ ethanol was produced 21.70 grams of brown ethanol extract. According to Sadek, ethanol has polarity index of 5.2 and has a $100 \%$ solubility in water will dissolve the compounds that are polar to non-polar. Furthermore, ethanol extract was partitioned into three solvents having different polarities [17].

\section{B. Separation and Purification of Metabolites}

All condensed ethanol extract was diluted with ethanol-water mixture (3:7) as much as $250 \mathrm{~mL}$ until all dissolved, then ethanol was evaporated until the remaining extract in water. This water extract was partitioned successively with $\mathrm{n}$-hexane and chloroform, then were subsequently evaporated the solvent, it produced $6.29 \mathrm{~g}$ of n-hexane extract; 3.28 grams of chloroform extract, and 8.13 grams of water extract. The toxicity tests of The extracts towards larvae of $A$. salina was conducted, the result was shown in Table 1. 
Table 1. Results of toxicity test of extracts from partition results

\begin{tabular}{cc}
\hline Extracts & $\mathbf{L C}_{\mathbf{5 0}} \mathbf{( p p m )}$ \\
\hline$n$-heksane & 316.22 \\
Chloroform & 501.18 \\
Water & 446.68 \\
\hline
\end{tabular}

Based on the data in Table 1 above showed that the $\mathrm{n}$-hexane extract was the most toxic with $\mathrm{LC}_{50}$ values of $316.22 \mathrm{ppm}$. Then $\mathrm{n}$-hexane extract ws separated and purified. The separation of the components in the n-hexane extract used column chromatography with a stationary phase of silica gel 60 (70-230 mesh ASTM) and a mobile phase mixture of $\mathrm{n}$-hexane - chloroform $(2: 8)$. Eluat was accommodated each $5 \mathrm{~mL}$. In this process produced 168 bottles of eluates. The stain patterns of all eluates were evaluated with thin layer chromatography. Based on the pattern of the stain, it was obtained three fractions $\left(\mathrm{F}_{\mathrm{A}}, \mathrm{F}_{\mathrm{B}}\right.$, and $F_{C}$ ) as shown in Table 2.

Table 2. Column chromatography results oh n-hexane fraction

\begin{tabular}{cc}
\hline Fractions & Number of bottle \\
\hline $\mathrm{F}_{\mathrm{A}}$ & $1-55$ \\
$\mathrm{~F}_{\mathrm{B}}$ & $56-123$ \\
$\mathrm{~F}_{\mathrm{C}}$ & $124-186$ \\
\hline
\end{tabular}

Furthermore, the three fractions were tested toxicity resulting toxicity data as shown in Table 3 below.

Table 3. Toxicity test result of the fractions

\begin{tabular}{cc}
\hline Fractions & $\mathbf{L C}_{\mathbf{5 0}}(\mathbf{p p m})$ \\
\hline $\mathrm{F}_{\mathrm{A}}$ & 794.32 \\
$\mathrm{~F}_{\mathrm{B}}$ & 50.11 \\
$\mathrm{~F}_{\mathrm{C}}$ & 630.95 \\
\hline
\end{tabular}

Based on the results of the toxicity tests above showed that fraction $\mathrm{B}\left(\mathrm{F}_{\mathrm{B}}\right)$ was the most toxic with $\mathrm{LC}_{50}$ of $50.11 \mathrm{ppm}$. If we compare to the toxicity of $\mathrm{n}$-hexane extract, the $F_{B}$ was higher toxicity. This indicated that the toxic compounds were more concentrated on $F_{B}$ and the compounds were antagonists (the purer was the more toxic).

\section{Anticancer Test}

Anticancer activity against $\mathrm{HeLa}$ cells was determined by MTT method. The principle of the MTT test was the mechanism yellow discoloration of tetrazolium salt (3-(4,5-dimethyltiazol-2-yl)-2,5-

dipheyiltetrazoliumbromide) which reduced to a crystal purple formazan in the mitochondria of living cells. MTT was absorbed into living cells and broken through the reduction reaction by reductase enzymes in the mitochondrial respiratory chain into formazan dissolved in $10 \%$ of purple SDS [6].
Table 4. Data of absorbance of isolates toxic $\left(\mathrm{F}_{\mathrm{B}}\right)$

\begin{tabular}{|c|c|c|c|c|c|}
\hline \multirow{2}{*}{$\begin{array}{c}\text { Sampel } \\
(\text { ppm) }\end{array}$} & \multicolumn{3}{|c|}{ Repetition } & \multirow{2}{*}{ Average } & \multirow{2}{*}{$\begin{array}{c}\text { Inhibition } \\
(\%)\end{array}$} \\
\hline & OD1 & OD2 & OD3 & & \\
\hline 100 & 0.045 & 0.052 & 0.049 & 0.048 & 75.75 \\
\hline 50 & 0.062 & 0.056 & 0.03 & 0.049 & 75.25 \\
\hline 25 & 0.071 & 0.056 & 0.04 & 0.056 & 71.71 \\
\hline 12.5 & 0.075 & 0.063 & 0.07 & 0.069 & 65.15 \\
\hline 6.25 & 0.098 & 0.083 & 0.09 & 0.090 & 54.54 \\
\hline 3.125 & 0.102 & 0.100 & 0.100 & 0.100 & 49.49 \\
\hline 1.56 & 0.125 & 0.115 & 0.117 & 0.119 & 39.89 \\
\hline 0.78 & 0.166 & 0.158 & 0.167 & 0.163 & 17.67 \\
\hline 0.39 & 0.182 & 0.178 & 0.175 & 0.178 & 10.10 \\
\hline 0.195 & 0.185 & 0.187 & 0.185 & 0.186 & 6.06 \\
\hline Cell control & 0.195 & 0.197 & 0.202 & 0.198 & 0.00 \\
\hline
\end{tabular}

The absorbance of formazan formed was measured with a microplate reader at a wavelength of $595 \mathrm{~nm}$ with triplo treatment. The stronger the purple color intensity, absorbance will be higher, this suggested that the more MTT absorbed into living cells and broken through the reduction reaction by reductase enzymes in the mitochondrial respiratory chain, thus formazan formed was also growing. Data obtained from the MTT cytotoxicity assay was a value of absorbance or optical density (OD), then the average OD values were converted to $\%$ inhibition. The observation of absorbance and calculation of $\%$ inhibition of HeLa cells after being given a toxic isolates $\left(\mathrm{F}_{\mathrm{B}}\right)$ the sponge $H$. erecta was presented in Table 4.

Based on the data on table 5 , it can be made the correlation between the concentration of the sample and \% inhibition to calculate IC50\%. The correlation data of sample concentration against \% inhibition can be seen in Table 5 .

Table 5. Data of correlation between concentration and the inhibition

\begin{tabular}{cc}
\hline Concentration, $\mathbf{x}(\mathbf{p p m})$ & Inhibition, $\mathbf{y}(\boldsymbol{\%})$ \\
\hline 100 & 75.75 \\
50 & 75.25 \\
25 & 71.71 \\
12.5 & 65.15 \\
6.25 & 54.54 \\
3.125 & 49.49 \\
1.56 & 39.89 \\
0.78 & 17.67 \\
0.39 & 10.10 \\
0.195 & 6.06 \\
0 & 0.00 \\
\hline
\end{tabular}


Based on the data above, it can be created regression line models: $\mathrm{y}=\mathrm{ax}+\mathrm{b}$, in order to obtain the regression line equation: $\mathrm{y}=0,624 \mathrm{x}+30.97(\mathrm{R} 2=0.443)$. The graph of concentration versus \% inhibition for determination of IC50 values was discribed in Figure 1.

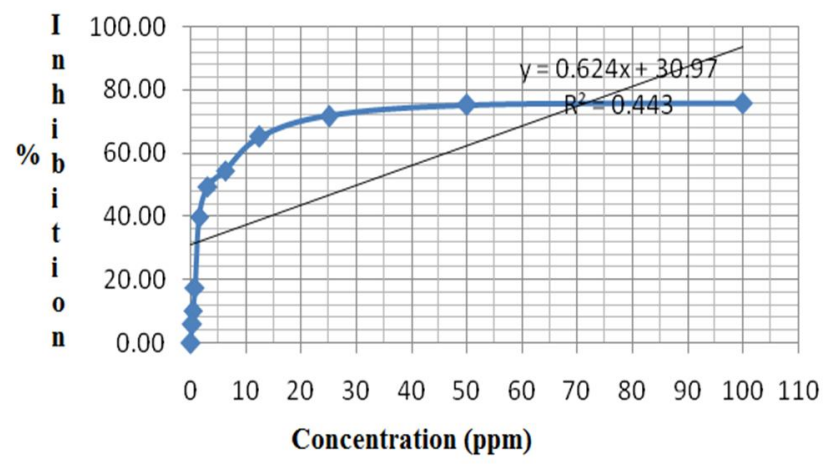

Figure Graphs the correlation between concentration 1. versus $\%$ inhibition

IC50 can be calculated through the regression equation: $50=0.624 \mathrm{x}+30.97$; where $\mathrm{x}=30.497$. So the IC50 of toxic isolate isolated from ethanol extract of $H$. erecta was $30.497 \mathrm{ppm}$. Anticancer activity of $30.497 \mathrm{ppm}$ was categorized into moderate activity [3], [11]. When it was compared to the IC50 of ethanol extract of $H$. erecta of $26.35 \mathrm{ppm}$ [5], [13], it showed a decline anticancer activity against HeLa cells after purified. This proved the phenomenon that compounds that have biological activity derived from biological materias were generally synergisti.

\section{Phytochemicals Test}

The active anticancer isolates above $\left(\mathrm{F}_{\mathrm{B}}\right)$ were tested phytochemically to determine the compound. Phytochemical test results was presented in Table 6.

\begin{tabular}{|c|c|c|c|}
\hline \multicolumn{4}{|c|}{$\begin{array}{l}\text { Results of Phytochemical Test of Isolates } \\
\left(F_{B}\right)\end{array}$} \\
\hline Group of compounds & Reagents & $\begin{array}{c}\text { Changes of } \\
\text { colour }\end{array}$ & Conclusion \\
\hline Alkaloids & Dragendrof & $\begin{array}{l}\text { Red } \\
\text { precipitate }\end{array}$ & $\begin{array}{l}\text { Positive } \\
\text { alkaloids }\end{array}$ \\
\hline Flavonoids & $\begin{array}{l}\mathrm{NaOH} 10 \% \\
\mathrm{H}_{2} \mathrm{SO}_{4} 50 \%\end{array}$ & $\begin{array}{l}\text { No changes } \\
\text { No changes }\end{array}$ & $\begin{array}{l}\text { Negative } \\
\text { Negative }\end{array}$ \\
\hline Triterpenoids/Steroids & $\begin{array}{l}\text { Lieberman- } \\
\text { Burchard }\end{array}$ & Green & $\begin{array}{l}\text { Positive } \\
\text { Steroids }\end{array}$ \\
\hline Polyphenols & $\mathrm{FeCl}_{3} 1 \%$ & Black & $\begin{array}{l}\text { Positive } \\
\text { Polyphenols }\end{array}$ \\
\hline Saponin & $\begin{array}{l}\text { Fom } \\
\text { test/Froth } \\
+\mathrm{HCl} 2 \% \\
\end{array}$ & No changes & Negative \\
\hline
\end{tabular}

\section{CONCLUSION}

Based on the above results it can be concluded :

1. Isolate Toxic obtained from the ethanol extract of $H$. erecta from the waters of Pari Island, Thousand Islands,
Jakarta has anticancer activity against HeLa cells with IC50 of $30.497 \mathrm{ppm}$.

2 . The phytochemical test results showed that the anticancer isolate was positive containing alkaloids, steroids, and polyphenols.

\section{ACKNOWLEDGMENTS}

Writers would like to thank to all those who helped to conduct the study. We also appreciate to the Directorate of Research and Community Service, Directorate General for Strengthening Research and Development, Ministry of Research, Technology and Higher Education, Republic of Indonesia, which has funded this research through competitive grants for Fiscal Year 2016. We are also grateful to the Institute for Research and Community Service (LPPM) Udayana University who have contributed proposing this research to be funded. May God bless you all.

\section{REFERENCES}

[17] Astuti, P., Alam, G., Hartati, M.S., Sari, D., dan Wahyuono, S. Cytotoxic Test of Alkaloids of Sponge Petrossian sp: A Potential development as Anticancer. "Uji Sitotoksik Senyawa Alkaloid dari Spons Petrosia sp: Potensial Pengembangan sebagai Antikanker". Majalah Farmasi Indonesia. 2005. 16 (1) 58-62.

[18] Calabresi, P., and Chabner, B. In: Gilman, G.E., Rall, T.W., Taylor, O., (Eds). The Pharmacological Basics of Therapeutis, 8th, ed. Pergamon Press, USA.1991.

[19]Cho, S. G., Valerie, H.L., Wu, X.H. Novel Cytotoxic Polyprenylated Xanthones from Garcinia gaudichaudii. Tetrahedron 1998; 54 : 10915-24.

[20] Cram, W.R., Stewart, C.F., In: Herfindal, E.T., Gourley, A.B., and Hart, L.L., (Eds). Clinical Pharmacy and Therapeutics, 5th ed., Maryland USA: Williams and Wilkins. 1992.

[21]Dira Swantara, I M. dan Rita, W. S. anticancer activity sponge Hyrtios erecta extract. "Aktivitas antikanker ekstrak spons Hyrtios erecta". Indonesian Journal of Cancer. 2015.9 (4): 141-145.

[22] Doyle, A, Griffiths, J.B. Cell and Tissue Culture For Medical Research. New York: John Wiley and Sons Ltd. 2000.

[23] Green D., Tew, K.D., Hisamatsu, T., and Schein, P.S. Correlation of Nitrosourea Murine Bone Marrow Toxicity with Deoxyribonucleic Acid Alkylation and Chromatin Binding Sites. Biochem. Pharmacol., 1982. 31, 1671-1679.

[24] Herzig R.H., Hines, J.D., and Herzin, G.P. Cerebellar toxicity with high-dose cytosine arabinoside. J. Clin. Oncol., 1987. 1: 927-932.

[25] Hoppe, W. F. dan M. J. M. Reichert. Predictable Annual Mass Release of Gametes By The Coral Reef Sponge Neofibularia Nolitangere (Porifera: Demospongiae). Marine biology. 1987. 94: 277-285.

[26] Jemal, A. Murray, T. Ward, E. Samuels, A, Tiwari R. C., Ghafoor A., Feuer E.J., Thun M.J. Cancer statistics. CA Cancer J Clin 2005. 55:10-30.

[27] Kumar, P. Praveen, S. Kumaravel and Lalitha, C. Screening of Antioxidant Activity, Total Phenolics and 
GC-MS Study of Vitex Negundo. African Journal of Biochemistry Research. 2010. 4(7): 191-195.

[28] Lorgan, P.C., Crasey, T., and Coleman, R.E. Drugs. 1996. $51: 571-584$.

[29] Maruthupandian, A. and Mohan, V.R. GC-MS analysis of some bioactive constituents of Pterocarpus marsupium R. International Journal of ChemTech Research. 2011. 3(3): 1652-1657.

[30] Meyer, B.N., Ferrigni, N.R., Putman, J.E., Jacobsen, L.B., Nichols, D.E., dan McLaughin, J.L., Brine Shrimp: A Convenient General Bioassay for Active Lant Constituents. Planta Medica, 1982, 45 : 31-34.

[31] Ohashi, K., Winarno, H., Mukao, M., Shibuya, H. Preparation and Cancer Cell Invasion Inhibitory Effects of C-16 Alkynic Fatty Acid. Chem. Pharm. Bull. 2003. 51(4) 463-466.

[32] Pettit, G. R. Natural Product. Natural Product Report, 1996. 59: 812-821.

[33] Sadek, P. The HPLC Solvents Guide. WileyInterscience. 2002.

[34] Steven, Colegate, Russel. Detection, Isolation, and Structural Determination of Albany. California. London. Crc Press. 1993.
[35] Sukardiman, Rahman A, Pratiwi, F.N. Pre-screening test of Anticancer Activity Ether and Methanol Extracts of Marchantia cf. planiloba Steph. With Death Test Methods shrimp larvae and densitometry Profile Active Extracts. "Uji Praskrining Aktivitas Antikanker Ekstrak Eter dan Ekstrak Metanol Marchantia cf. planiloba Steph. Dengan Metode Uji Kematian Larva Udang dan Profil Densitometri Ekstrak Aktif'. Surabaya: Fakultas Farmasi, Universitas Airlangga. 2004.

[36] Widyastuti, S. Toxicitytest of Iprih Leaf Extract (Ficus glabella Blume) against Artemia salina Leach and Thin Layer Chromatography Profile. "Uji Toksisitas Ekstrak Daun Iprih (Ficus Glabella Blume) Terhadap Artemia salina Leach Dan Profil Kromatografi Lapis Tipis". Skripsi. Surakarta: Fakultas Farmasi, Universitas Muhammadiyah. 2008.

[37] Winarno, H. Antiproliferative Activity of Octadeca8,10,12-trynoic Acid Agains Human Cancer Cell Lines. Berita-Biologi. 2009. 9(4): 343-348.

[38] Yohana, Arisandi, dan Andriani Y. Efficacy of Medicinal Plants. "Khasiat Tanaman Obat". Jakarta: Pustaka Buku Murah; 2005. 